物を導れた範囲での発展でしかありえない状況にな つているといえる。(1960年11月30日受理)

\title{
ANALYSE HISTORIQUE DE LA RÉGION DE SÉRICICULTURE
}

\section{Akira EBATO}

Utilisant les résultats des enquêtes que nous avons faites dans les régions de sériciculture du departement de Nagano, de Gumma et de Fukushima, nous avons montré comment le développement du capitalisme a affecté les activités économiques de leurs diverses localités. Nous pouvons en conclure que la classe rurale dans ces régions de sériciculture, s'est différenciée d'une manière bien! normale jusqu'à la fin de l'ère Meiji. Cela provient du fait que l'agriculture de ces régions avait indirectement participé à la soirie : industrie trés avantageuse liée directment au marché étranger.

Pourtant, cette évolution normale, qui ne se trouve que dans une partie des régions de "champs" (ceuxci étant opposés aux rizières) constitute une exception à la différentiation habituelle que l'on trouve dans la classe paysanne japonaise. Dans les régions de rizières, qui couvrent d'ailleurs la plupart des terres cultivées au Japon, la classe rurale a connu une différentiation anormale: le propriétaire le fermier, qui a été favorisée par des fermages exagérés.

Les paysans ainsi appauvris, étaient obligés de trouver leurs gains supplémentaires en travaillant temporairement chez les paysans aisés eux-mêmes devenus entreneurs demi-commerciaux: le commerce de la sériciculture ycompris. L'industrie n'avait pas encore fait assez de progrès pour absorber la main d'o euvre disponsible de la classe rurale.

Le progrès rapide de la monopolisation industrielle, qui eût lieu entre 1910 et 1920 arrêta le progrè exceptionnel que nous avons constaté dans les régions de "champs", et la classe rurale dans son ensemble, commença une évolution de plus en plus homogéne, connue sous le nom de "standalisation au niveau moyen".

\section{常盤沛度らびに鹿島灘陸棚の海底地形と底質*}

\section{茂木昭夫・岩淵 義 郎}

\begin{abstract}
摘要 利根川河口から仙台湾にわたる，常磐沖ならびに鹿島灘の陸棚を考察した結果，陸棚は $20 \mathrm{~m}$ 以浅，25〜 $50 \mathrm{~m}, 40 \sim 60 \mathrm{~m}$ および 100 140 m の 4つの地形面からなることが知られた. $20 \mathrm{~m}$ 以浅の海底は，甚だ狭いなめ らかな斜面で 現在の海面に関して形成されつつある現海成面である. $25 \sim 50 \mathrm{~m}$ 平坦面は, 平均巾 $10 \mathrm{~km}$ 有し, 多数の明瞭な海底谷によつて, 浅く刻まれた起伏のある海底を示し, その表面には, 広く岩盤と粗粒堆積物が分布 している. 40〜60 mの海底は，海底谷末端に狭く連なり，そこにはやはり粗粒堆積物が分布している.これらの海 底地形，底質分布から，筆者等は次のような地形発達を考えた。洪積世最末期の海面低下の際，現在の $100 \sim 140$ $\mathrm{m}$ 平坦面が形成され，この海面を侵蝕基準面として，現在の久慈川の地下に埋没している $-60 \mathrm{~m}$ の旧谷が形成さ れた。 その後海進法じて, これらの谷は埋没され, 現在の $50 \sim 100 \mathrm{~m}$ の斜面が形成された.この海進の途中で海 面は一時停止し，そこに現在の $25 \sim 50 \mathrm{~m}$ の広、平坦面を形成したが，その後再び海退に移り，海面は現在の水深 40 50 m 付近に停まつた。この時, 河川は延長川となり陸化した $25 \sim 50 \mathrm{~m}$ 平坦面を下刻して, 現在の海底谷を 形成し，-40 60 m 付近には，狭い平坦面と粗い底質を残した. 再び海進に転じ，海面は現海面より $4 \sim 5 \mathrm{~m}$ 高い 所に位置した後, 海退に移り, 現在の海岸平野を形成した.
\end{abstract}

\section{1.をえがき}

我が国における海底地形の研究は，近年非常に活
潑になつてきたが，特に関東地方周辺の大陸棚の地 形に関する問題は，陸上の地形・地質についての，

* 本稿は1960 年日本地質学会年次大会において発表したものに，加等したものである. 
豊富な資料のたすけによつて，多くの人々によつて 研究が行われた。しかし陸上にくらへて，海底の資 料は未だ十分でなく，陸棚の形成に関する問題につ いては，未だ意見の一致を見るまでに至つていない． 鹿島灘の海底地形老研究した吉川虎雄は1”，陸棚 を $40 \mathrm{~m}$ 以浅と, $100 \mathrm{~m}$ 内外の 2 段の平坦面に区分し， 鹿島漠倠沿岸のように，広い洪積台地や海岸低地の連 なる地域では，陸棚は $40 \mathrm{~m}$ 以浅の平坦面のみから なることを認め, 100～160m 平坦面を上部更新統が 埋積し，その後に $40 \mathrm{~m}$ 以浅の海蝕面が，上部更新統 を侵蝕して形成されたと推定した。これに対し，杉 村新 ${ }^{2)}$ ，貝塚秌平 ${ }^{3)}$ は，やはり鹿島湢沿沿岸の陸棚を 2 段の平坦面に区分したが，100m 内外の平坦面を， 沼，有楽町 stage の堆樍物の基底面に対比し，40m 以浅の平坦面を，現海蝕面とした.

1955 年頃から約 4 年間にわたつて, 第三管区海上 保安本部水路部と第二管区海上保安本部水路部によ り，鹿島灘から仙台湾にわたる，1:5万の精密な沿 岸測量が実施されたこの測量の結果，この海域の 睦棚の地形は，かなり詳細に判明した。ささら1956 年，1957 年の両年にわたつて，鹿島漠保の一部である 東海村沿岸において，1：5千および1：1 千の精密 測量が行われたため, 水深 $40 \mathrm{~m}$ 以浅部の海底地形・ 底質分布は，著しく詳細に判明するに至つた。

この新しい資料について見ると，全海域にわたつ て，明らかに $50 \mathrm{~m}$ 以浅と，100m 内外に平坦面が認 められる。しかし後述するように，この $50 \mathrm{~m}$ 以浅 の地形・底質などから考えると，この平坦面が，現 在の波浪に関して形成されつつある海成面ではなく， 古い地形面であることが明かである、東海村の調查 結果によると， $50 \mathrm{~m}$ 以浅の平坦面は，水深 $25 \mathrm{~m}$ 付
近を境に，明かに $25 \mathrm{~m}$ 以浅の海底と，25～50m の 平坦面に分けられる。東海村沖から連続して発達す る，常盤沖並に鹿島灘の陸棚は，したがつて $25 \mathrm{~m}$ 以 浅の地域と，25～50m 平坦面，および 100 $\mathrm{m}$ 内外の 平坦面の，3つに区分されなければならない4).

またこの測量により，陸棚を浅く刻む，多数の海 底谷の存在が明かになつたことは，他の地域に見ら れない著しい特徵であつて，陸棚の成因を解く 1 つ の手がかりを与えるものとして，注目される：筆者 等は, これらの地形的特徴に注目し, 海底地形と底 質分布について考察した。

\section{2. 東海村沖}

1）現海成面（20m 以浅）東海村沖に打いて1: 5 千および $1: 1$ 千の精密調査を奏施した結果, 水深 $20 \mathrm{~m}$ 以浅に，狭い堆積面が，存在することを知つた。

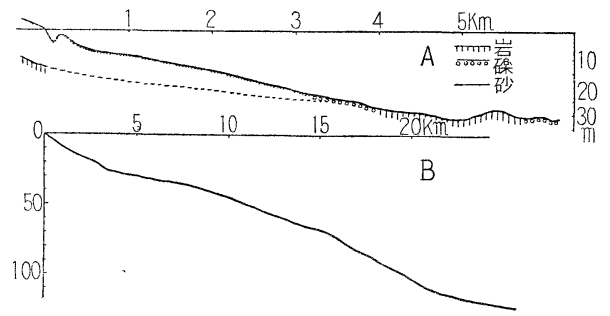

第 1 図 東海村沖の海底断面

すなわち海底断面を見ると（第1図），水深 $7 \sim 12 \mathrm{~m}$ 間に，やや平坦な所が存在し，12m付近から，わう かに傾斜を增して深くなるが，25m 以深に至ると再 び平坦となる， $25 \mathrm{~m}$ 以浅の海底を見ると， offshore bar の発達する砕波帯を除いては，極めてなめらか な海底があつて，その断面はわずかに上方に山面を 向けているが，一般に明膫な break を示さずに， $25 \mathrm{~m}$ 以深の平坦面に移つている。 一方 $25 \mathrm{~m}$ 以深の

1）吉川虎雄（1953）：日本周縁の陸棚に関する 2,3 の考察。打茶の永女子大自然科学報告， 4, $1,138 \sim 150$.

2) 杉村 新 (1850)：関東地方周辺の海底段丘その他について，地理評.，23,10～16.

3）貝塚棸平 (1958)：関東平野の地形発達史。地理評, 31, 2

4）後述するように $25 \sim 50 \mathrm{~m}$ 平坦面は，一部において明かにさらに 2 段に区別されるから，厳密には，4つ の地形面から構成される。 
海底は，全体的には水平に近い平坦面であるが，そ の表面は凹凸が激しく,25m 以浅のなだらかな地形 とは，明かに趣を異にする。

$20 \mathrm{~m}$ 以浅部と, 25 50 m 平坦面の異質を示す, 最 も明かな証拠は，底質に見られる粒度分布であろう。 第 2 図は $M d \phi$ を水深に沿つて投影したものである.

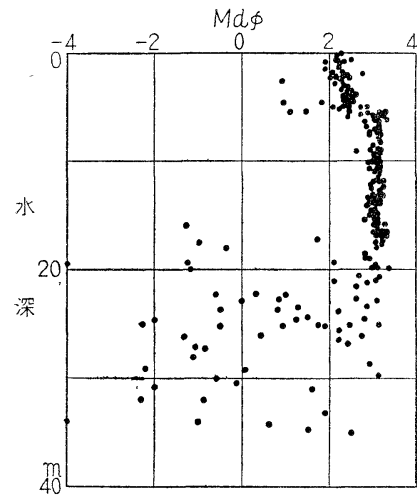

第 2 図 東海村沖における底 質の粒径と水深との関係
これによつて見る

と, 海岸砂は+2.0 〜ー2.0にわたつ て，場所によりか なり変動している が，一般に粗く， 海底に大ると， offshore bar の所 で，甚だ複雑な分 布を示すが，潮次 沖のうに細粒とな り，水深 $6 \mathrm{~m}$ 付近より+3.0内外の，ほぼ一定の粒 度を示しながら，沖合に向う。しかるに水深 $20 \mathrm{~m}$ を 越えると，突然負の数值を示す地点が現れ，0〜一 4.0 と+2.0〜+3.0の 2 つの group に分れるよう になる，前者は礫抢よび樂まじり粗砂であつて，後 者とは甚だ不協和的である。この状態を底質分布に よつて見ると，礫や岩が水深 $25 \mathrm{~m}$ 付近から patch 状にあらわれ，それらの間を埋めて，砂が堆積して いる状況を知ることができる(第 3 図)。すなわち前 者は，過去のある時代に堆積したものであることを 示し，後者は，現在堆積しつつあるものであること 走示す.

この事実をさらに証拠だてるものに，東海村海岸 および海底で実施された，ボーリング資料がある。

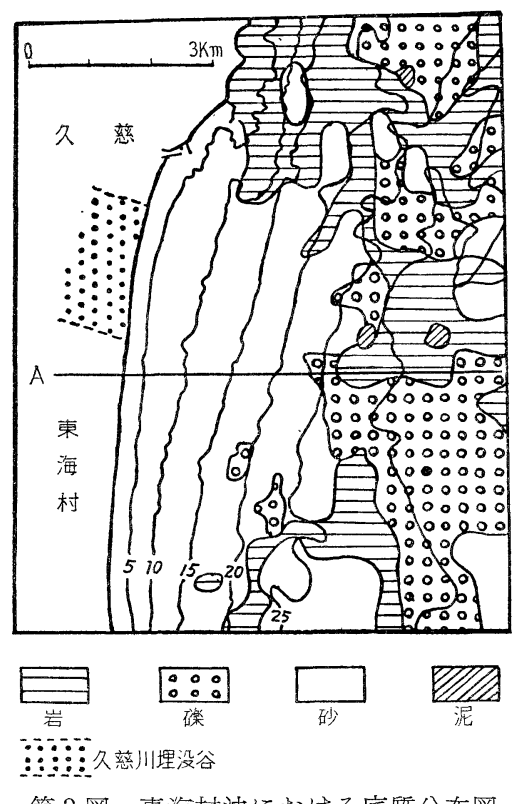

第 3 図東海村沖における底質分布図

奈須・加賀美などは，このボーリング資料を分析し た結果，東海村の砂浜の下に，埋没した段丘面が存 在することを明かにし，これらの段丘面が $20 \mathrm{~m}$ 以深 の平坦面に対比されることを報告した ${ }^{556)}$ 。すなわ ち， $20 \mathrm{~m}$ 以深の平坦面に連なる段丘面を，現在の砂 浜矛よび $20 \mathrm{~m}$ 以浅の砂質堆積物が，埋めているこ とが分る(第1図).

1956 年 12 月と 1957 年 8 月の両度の東海村調查 結果からの，水深比較によると，20m 以浅の砂質海 底には，測深誤差を考慮しても，なお明かな季節変 化が見られた7゙.このことは，少くとも20m 以浅の 海底は，現在の波浪の影響下にあることを示すもの である.

また先に筆者の一人は，東海村沿岸に発達する， offshore bar の大きさの分布が, $20 \mathrm{~m}$ 以浅の海底の 広さと密接な関係があることを指摘した8)。 そして

5）奈須紀幸・飯島 東・加賀美英雄 (1959）：東海村沖海底調查報告書 (中間報告).

6）加賀美英雄・飯島 東・奈須紀幸（1960）：荻城県東海村沖の陸棚堆積物について．地質雑.，66，778， (演旨)

7）茂木昭夫（1960）：東海村沿岸の地形変化について．地理評.，33，8，393～411.

8）—(1959）：江ノ島打よび東海村付近沿岸の地形. 地理評., 32, 3, 121〜134. 
$30 ・ 40 ・ 50 \mathrm{~m}$ などの等深線との閒には，そのような 関係を認めることはできない。この事実は，波の進 行に伴う，海底面との摩擦による energy の消費は ，20m 以浅に至つて，極めて顕著であることを示す ものである.

以上の諸事実は，現在直接波の影響下にある水深 が $20 \mathrm{~m}$ 以浅であることを示すものである。したが つて $20 \mathrm{~m}$ 以浅の砂質堆樍面は, 現在の海面に関し て形成されつつある海成面であつて，20m 以深の海 底とは，明かに区別される。

2） 25 50m 平坦面 次に $25 \sim 50 \mathrm{~m}$ 平坦面を見 ると（第 1 図，第 13 図)，全体的には甚だ平坦であ るが，表面は起伏に富み，現海成面が約 $1.5 \mathrm{~km} の$ 巾を有するのに対し， $12 \mathrm{~km}$ のウを有していて甚な゙ 広い。その起伏は $10 \mathrm{~m}$ 未満の小さなものであるが， 現海成面や 100 ～140m 平坦面の，なめらかな地形 に比較して，著しい特徴を有するといえる。

この起伏な海底谷によるものであると思われるが， 地形上には，明瞭な谷形が示されていない， $20 \mathrm{~m}$ 以 深海底に，岩盤・礫があらわれてくることは，先に 述べたが，海底地形と底質分布との関係を見ると， 大体地形の高所に岩盤が露出し，低所を埋めて礫が 分布していることが知られる(第 3 図)。

この $25 \mathrm{~m}$ 以深における礫の分布を見ると（第 3 困，1つは新川の東北 $4 \mathrm{~km}$ の沖合から，沖の方に わたつて広く分布している礫带がある。この䃯帯は $20 \mathrm{~m}$ 以浅の砂帯から連続し， $1 \mathrm{~km}$ 以上の币を持ち ながら，沖の方に拡がつている。他法入慈川河口の 東方および東北方 $4 \mathrm{~km}$ の沖合に，見られる礫帯で あつて，この䃯帯は， $20 \mathrm{~m}$ 以浅の砂带との閒に，広 い岩盤帯をはさんで，砂带とは連続しない，海岸で 実施されたボーリングの結果，久慈川および新川の
地下には，深さ夫々 $60 ， 30 \mathrm{~m}$ に達する，厚い砂礫 層によつて埋められた，旧河谷が存在することが， 発見された910)、第 3 図には，これらの旧河谷の位 置を示す。これらの旧河谷は，その沖合海底に，そ の延長を有するはずであると考えられるが，海底に は，そのような深い海底谷の地形は見られない。し かし礫によつて埋められている海底低所は，多分に これらの旧河谷の延長となり得る可能性がある。そ の場合，沿岸砂带から，連続して分布する南の碟带 以外には，旧河谷の延長は考えられないであろう。 なぜなら，旧河谷の深さが，海岸においてー60m を 示しているのに対し，海底では，南の皪带以外は， -30m 以浅に岩盤が墥続して分布しているからで ある、したがつて久慈川の旧河谷は，現在の海岸か

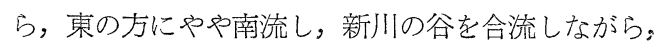
現在礫帯によつて示されている地域を，東のうに向 つていたものと推定される. 久慈川の旧河谷と, 南 の礫帯との位置的な関係は，旧久慈川谷が，現在の 河口より著しく南に開口していたことと，第 3 図の 砂帯の分布抢よび海底地形から, $20 \mathrm{~m}$ 以浅の砂質堆 積物が，旧河口付近を中心に，扇形に拡がつた，三 角州状の分布を示している事実から，旧久慈川谷一 一その旧三角州一一海底低所に見られる礫带とを結 びつけることは，位置的に決して無理な見方ではあ るまいと思う ${ }^{11)}$. 以上のように，この海底の碟带に よつて表示される部分は，旧久慈川筋にあたるもの で，この下には，海岸のボーリング結果に見られた ような, 一 $60 \mathrm{~m}$ 以上に達する, 深い谷が存在して, 埋没されているものと予想される.

次に $1: 5$ 万の測量結果から，この平坦面の地形 を詳細に検討すると，厳密には，この平坦面は $25 〜$ $35 \mathrm{~m}$ の面と 50 ～ $65 \mathrm{~m}$ の面の，2つの面からなつて

9）吉川虎雄・小池一之（1959）：東海村海岸調查報告書（第一報）。1１1.

10）前揭 4)，5).

11）加賀美等（前揭 5)）は，久慈川の旧谷を埋めている. 砂礫層の上部 $-7 \mathrm{~m}$ 付近に，埋没段丘面から連続。 する礫層が存在しており，これらの礫層は水深 $25 \mathrm{~m}$ 付近の海底磁に対比されると報告している。 
いるように思われる（第1図，第13 図)。加賀美 ${ }^{122}$ 等は，この海底の底質分布から，50〜60m 付近にお いて，再び底質の粒度が粗粒となることを指摘し， これらの省層を，東海村海岸地下の，-15m 内外の 埋没段丘礫層に対比した。しかし筆者等は，後述す るような理由から，むしろ久慈川埋没谷内にのみ見 られる，-40m 付近の磞層に対比されるものと考元 ている.

3） $50 \mathrm{~m}$ 以深 $50 \mathrm{~m}$ 以深の海底は，精密調査区 域外であるが, $1: 5$ 万の測量結果によると(第 1 図)， 水深 $50 \mathrm{~m}$ 付近上り水深 $100 \mathrm{~m}$ 付近までは，ゆるや かに沖の方に傾いた斜面があるが，水深 $110 \mathrm{~m}$ 付近 に至ると，再び平坦となり，陸棚外縁平坦面に移る。 この $50 \sim 100 \mathrm{~m}$ 斜面は，傾斜 $0^{\circ} 30^{\prime}$ で甚だゆるく， 表面は平滑で, その巾は $5.5 \mathrm{~km}$ に達して広い. 110 $\sim 140 \mathrm{~m}$ の陸棚外縁平坦面は, 巾 $20 \mathrm{~km}$, 傾斜約 $30^{\prime \prime}$ の水平に近い平坦面で，表面には起伏は見られず， 25～50m 平坦面とは異つた特徵を有する.

\section{3. 常盤南部沖}

1） $50 \mathrm{~m}$ 以浅の海底 i）海底地形……名浜か ら久慈川に連なるこの海域の海底地形は, 水深 $50 \mathrm{~m}$ 付近を境に，50m 以浅の起伏に富む複雑な海底と， $50 \mathrm{~m}$ 以深の，極文てなだらかな海底とに分れる。

$50 \mathrm{~m}$ 以浅の著しい起伏は，明瞭な海底谷と，海底 谷間の海脚とによるものである(第4 図)。これらの 海底谷の始まる深さは， $20 \mathrm{~m}$ 付近であつて，その未 端の深さは，いずれも大体水深 $50 \mathrm{~m}$ である。 $20 \mathrm{~m}$ 以浅には海底谷が存在しないので，起伏が小さく， $20 \mathrm{~m}$ 以深の起伏の大きい海底と, 明かに区別される.

この $20 \mathrm{~m}$ 以浅の海底は， $2 \mathrm{~km}$ の巾をもつて海崖 に連なり，その表面には若干の起伏がある。一般に 岬の沖では，細かい複雑な起伏を示してやや浅く， 砂浜の所では。”甚だなめらかな地形を示し，岬沖の

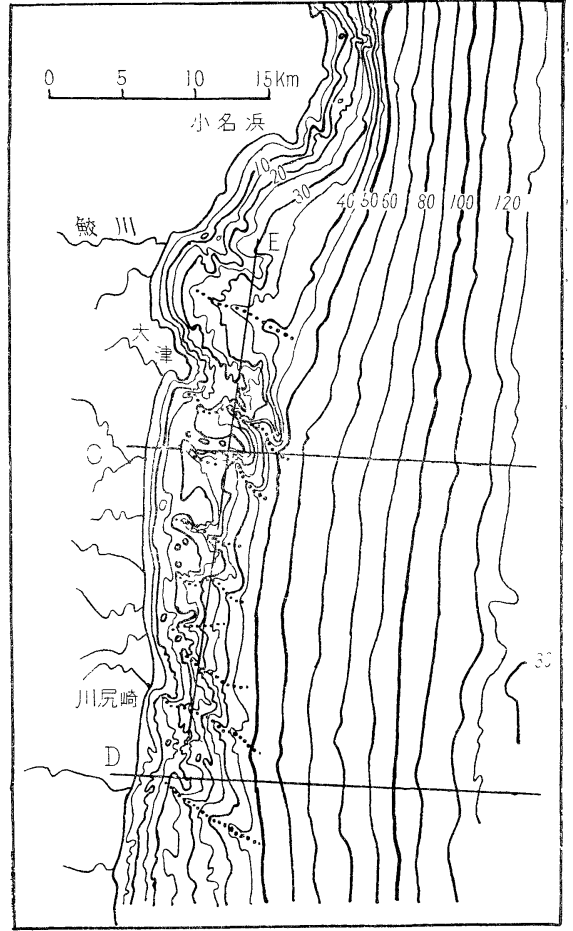

第 4 汹常磐南部沖海底地形図

海底よりも幾分深い，底質分布抢よび音響測深記録 から見ると，これらの岬沖の海底は，岬から続く岩 盤の露出している所であり，岬間のなめらかな海底 は，砂の堆積している所である。しかし川尻畸以南 の $20 \mathrm{~m}$ 以浅海底は, 全体的に複雑な地形であり, 底 質も岩盤を示している 川尻崎以南の海岸は，比高 $10 \mathrm{~m}$ の海蝕崖が連綿と連なる所であり, 以北の海岸 は，狭い河口平野を形成している。この $20 \mathrm{~m}$ 以浅 の海底は，先に東海村沖において考察した結果から 推して，現在の海面に関して形成されつつある，海 成面であると考えてょいであろう，岩盤の露出して いる所は，目下波浪その他によつて，侵蝕されつつ ある侵蝕面であり，砂の分布している所は，砂の堆 積面であると考えられる，石井 ${ }^{13}$ によると，小名浜 の冲積層下には， $-15 \mathrm{~m}$ 付近に薄い礫層の存在する

12）前揭 5).

13）石井靖丸（1955）：港湾地带の沖積層とその性質．海岸工学講演集．93～98. 
[34. 3

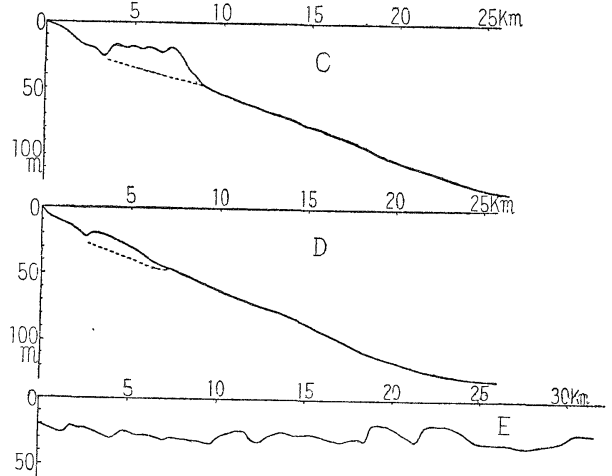

第 5 図 常盤南部沖海底断面図

ことが報告されており，また大津付近の海岸におけ るボーリング結果によると ${ }^{14)},-15 \mathrm{~m}$ 付近で多賀層 群に達することが知られているから，20m 以浅の砂 質堆積物の厚さは, 約 $15 \mathrm{~m}$ 内外であると考えられる。

$20 \mathrm{~m}$ 以深の海底は, 極めて明瞭な海底谷と, 海脚 の交互する起伏のある海底である。これらの谷には， 谷巾の広い谷と，谷巾の狭い谷との 2 つの type が ある．前者は花園川・関根川・花貫川などの，比較 的大きな河川の沖に存在するものであり，後者は逆 に，短小な河川に続くものである. 注目されること は，これらの海底谷は，明かに陸上河川に密接に結 びつくことである，短小な河川と，谷巾の狭い海底 谷との連続関係は，特に明瞭である。谷币の広い海 底谷と陸上河川との関係は，前者程明かでないけれ ども，各河川流域の冲積平野と，海底谷との関係に ついて見ると，その連結関係は，極めて明膫で，河 川に沿つた冲積平野 (谷底平野) は，そのまま海底 の巾の広、谷に続いているのである（第4 図）。

次に海底谷間に見られる海脚の地形を見ると，い ずれも $15 \sim 20 \mathrm{~m}$ の一様な水深を示し，表面には細 かい起伏があるが，甚だ平坦で，その周囲の斜面は 一般に急峻である．特に各海脚の南側斜面に，共通

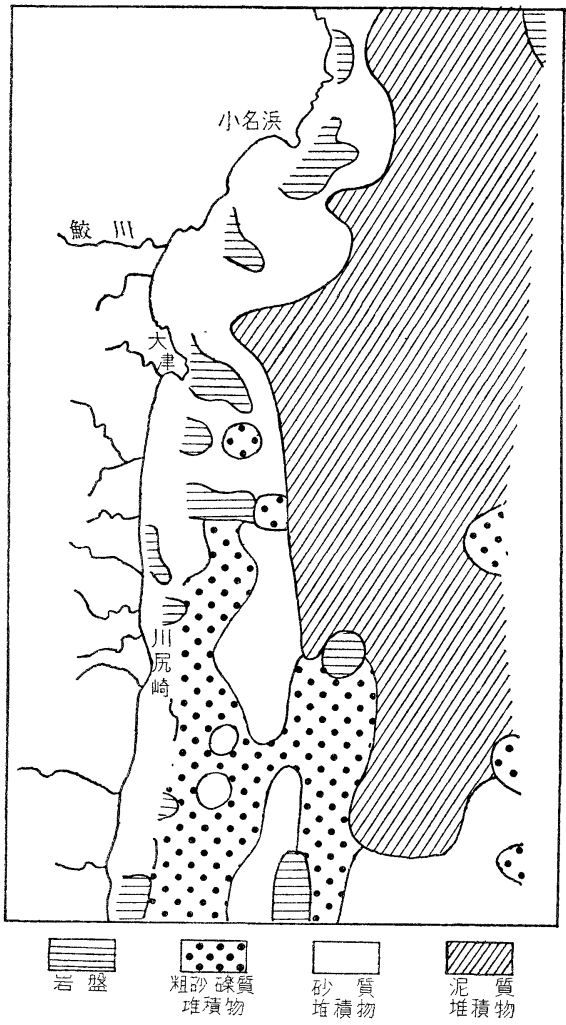

第 6 図常磐南部沖底質分布図

して急崖が見られることは，著しい特徴である（第 5 図)。この海脚の分布と陸上地形との関係を見る と，興味あることは，陸上の各河川間に発達してい る段丘の分布 ${ }^{15)}$ と，海脚の分布とが，明かに一致し ていることである.すなわち段丘の広く発達してい る海岸の沖には，広い海脚が発達しており（関根川 北岸段丘), 段丘が狭く带状に発達している所では, 海脚もその延長上に，狭く帯状に発達しているので ある ${ }^{16)}$. (花園川北岸段丘・同南岸段丘・花貫川南岸 段丘・梁津川北岸段丘）

ii）底質……の地域の底質資料は，1:5万の 測量に際して採取した資料の外に，昭和 32 年測量 船明洋によつて, $50 \mathrm{~m}$ 以浅の海底から採取した資料

14）常䑾炭鈗株式会社の御好意による。

15）大倉陽子 (1953)：常磐沿岸地方南部の地形. 地理評., 26, $52 \sim 62$.

16）段丘の分布と海脚の分布とに見られる関係は，大倉の段丘分布図と海底地形図とを比較参照されたい. 
第 1 表 常磐南部沖底質組成表（No. 1～106）

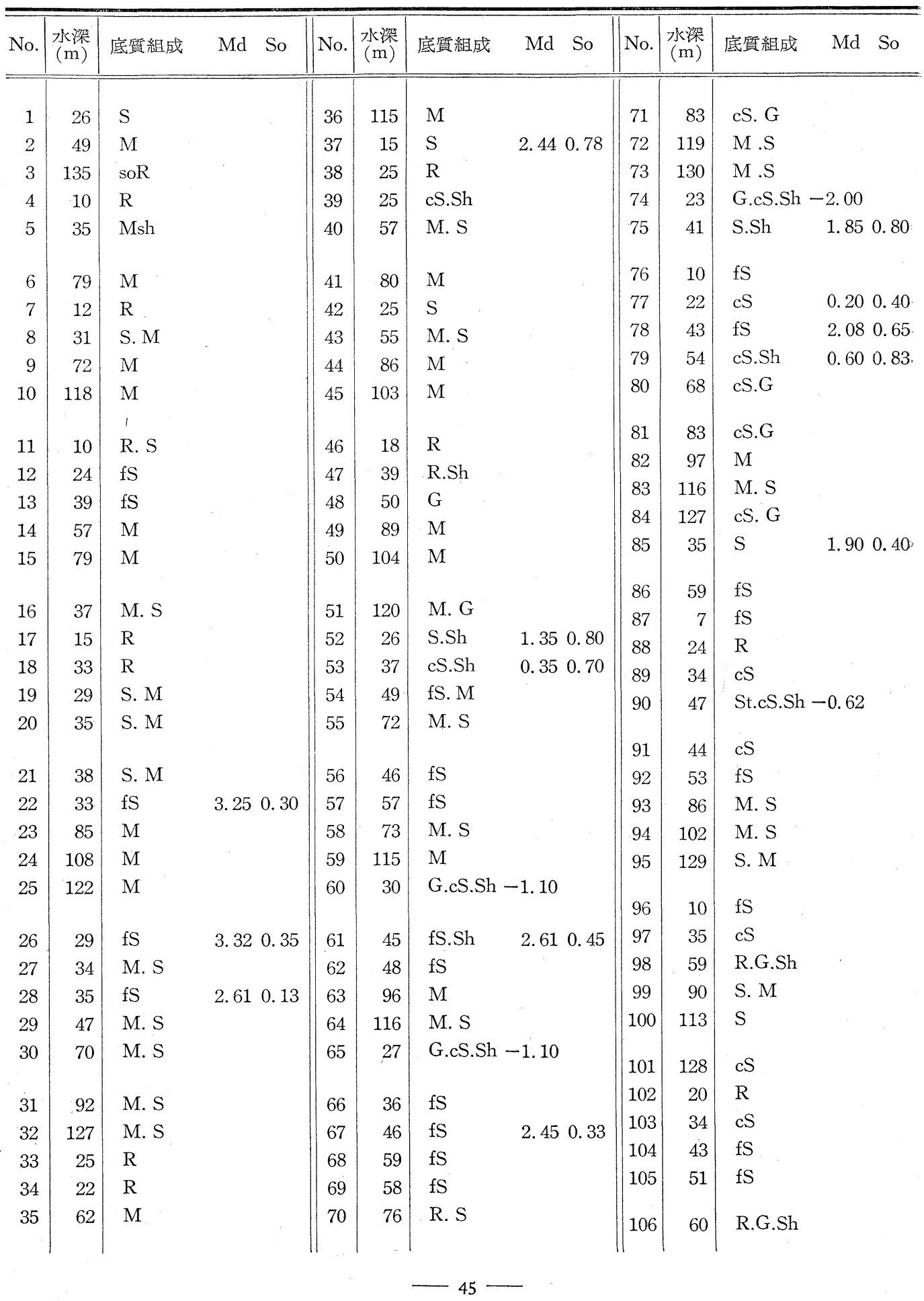




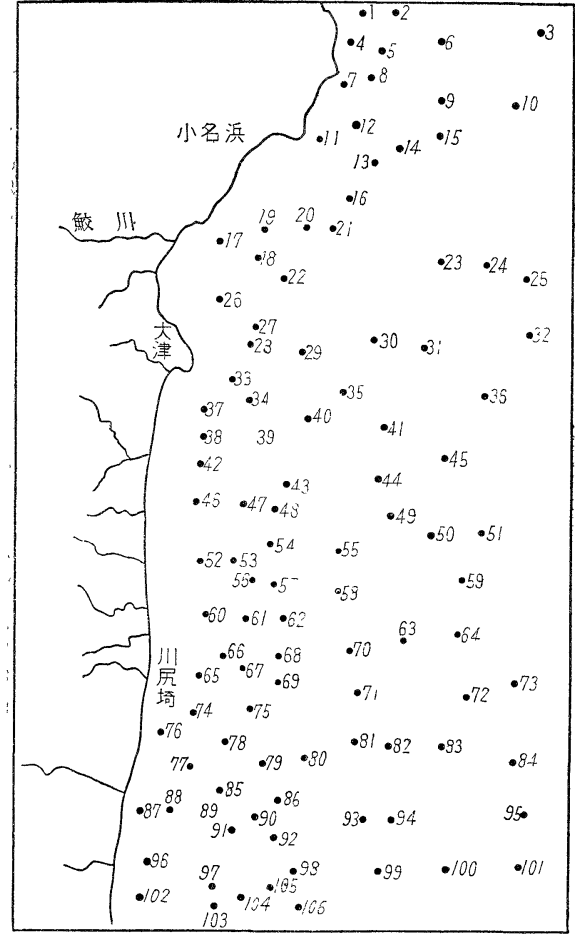

第 7 図 常磐南部沖底質採取地点図

とがある。これらの資料によつて底質の分布を見る と，岩盤は広く $50 \mathrm{~m}$ 以浅の海底加ら採取されてい る。その岩質は，この付近の陸上を構成する，第三 禾の凝灰質砂岩扎よびシルト岩である，前述の各海 脚からは，いずれも岩盤が採取されており，その上 に薄く礫・貝殼・砂をのせている．特に注意をひく のは，海脚閒の広い谷内扰よびそれに続く，30〜50 mの平坦面上からも，岩盤が採取されていることで ある.（花園川沖の広い谷 st 46, st 47)。礫はこれら の岩盤をおほつて広く分布している、いずれも円磨 されており，扁平な礫も多数採取された，その大き さは $20 \mathrm{~cm}$ 以上に達するものもある. 礫種は chert, sandstone, schist などで, 場所によつては amphibole も存在する。しかし圧倒的に多いのは chert である。 注目されるのは，岩盤から由来したと思わ机る tertiary の緲を含むことである。この礫は，他の古期
岩類と比較して大きい:これらの絲の分布を見ると， 川屃崎以北においては，水深 $30 \mathrm{~m}$ 以深の平坦面上 にのみ分布し，谷の内部は砂によつて埋められてい るが，川尻崎以南に沶いては，50m 以浅の海底に広 く樂が分布している。逆に砂質堆積物は北部に多く， 南部に少ない。

2）50m 以深の海底 $50 \mathrm{~m}$ 以深の海底は，110 $140 \mathrm{~m}$ に見られる平坦面と，50m から $110 \mathrm{mにわた}$ る斜面部とからなる。この斜面部は傾斜 $20^{\prime}$ のる いなめらかな斜面で，その币は約 $12 \mathrm{~km}$ に達する. ここの底質は，細砂・泥が圧倒的である，しかし川 尻崎付近より南部に执いては，粗粒で砂が多く，水 深 $80 \mathrm{~m}$ 付近まで gramule 含含む.

110 140m 平坦面は，殆んど水平で，表面には起 伏はない。底質はやや粗粒となり，粗砂・granule・ 細砂などが採取されている。

\section{4. 常盤北部沖}

1） $50 \mathrm{~m}$ 以浅の海底 i) 海底地形……原釜から 塩屋崎に連なるこの海域の陸棚の地形は，120m 以 深の陸棚外縁平坦面と, 北半部に広く発達する20～ $60 \mathrm{~m}$ 平坦面により特徴づけられている(第 8 図). $20 \mathrm{~m}$ 以浅の海底は, 地域によつて多少の広狭の差 はあるが，大体 $2.5 \mathrm{~km}$ の巾で海岸に連なる。この 地形は表面に細かい起伏があるが，36' の傾斜で海 万に緩やかに傾いた斜面である。一般にこの斜面は， 水深 $5 \sim 10 \mathrm{~m}$ まで特に急である。ここの底質は，海 蝕崖の発達している所では，広く岩盤が露出し，そ の表面を，砂礫が部分的に打ほつている。川の注ぐ 砂浜の沖は，一般に砂の堆積する所である。

25～50m 平坦面は，著しく特徴のある分布を示し ている、すなわち北部の原釜沖では，非常に広くて

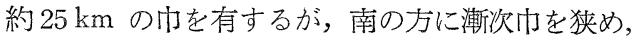
浪江の沖では約 $10 \mathrm{~km}$ となり,南の広野付近に至つ て，遂に消失する．この平坦面のも 1 つの著しい特 徽は，面上を浅く刻んた，多数の海底谷が存在する 
ことである 海底谷の始まる深さは，水深 $25 \sim 30 \mathrm{~m}$

で，乙の末端は 40〜 $60 \mathrm{~m}$ である。ここの海底谷は，

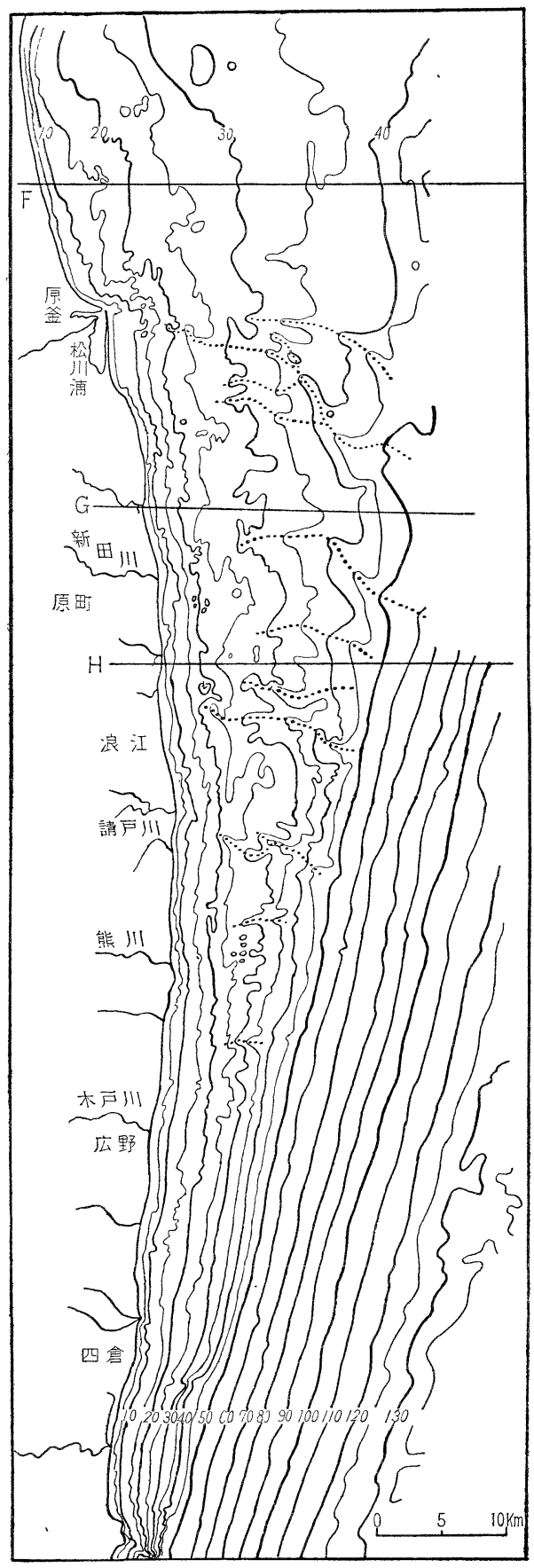

第 8 図 常船北部沖海底地形図
常盤南部沖の海底谷程明膫には，陸上河谷と結びつ かないが，いずれも陸上各河川の油に位置しており， その形は蛇行し，かつ支流を少つていて，著しく陸 上河川に類似している，海底谷と陸上河川とをへだ てる $20 \mathrm{~m}$ 以浅の海底は，その部分では殆んど砂が 堆積しており，両側の岩盤带の間に東西の带状をな す。したがつて陸上河谷と, $20 \mathrm{~m}$ 以浅の砂带および 海底谷とは，大体連続する。

ii）底質……の平坦面の底質を見ると，岩盤が 広く分布し，礫・粗砂などの底質によつて，特徴づ けられる。岩盤の分布する所は，平坦面上の突起部 で，その表面には，フジッボ・石灰藻・呀孔貝が付 着している.これらの岩盤は，この付近の陸上を構 成する第三系と同じ凝灰質シルト岩・砂岩からなる。 したがつてこの平坦面は，この第三系凝灰質砂岩・ シルト岩を侵蝕して形成された侵蝕面である。これ らの岩盤を，礫・碟交り粗砂・淘汰のよい細砂がお おつている．前二者はこの平坦面に広く分布するも ので，殆んど礫からなる資料は， st 14 に見られる が，最大礫は $60 \mathrm{~mm}$ を越えず，大部分中礫以下のも のである。礫交り粗砂は，st 63 のごとく，礫が 60 \%も含まれるものもあるが，大部分は $10 \sim 40 \% の$
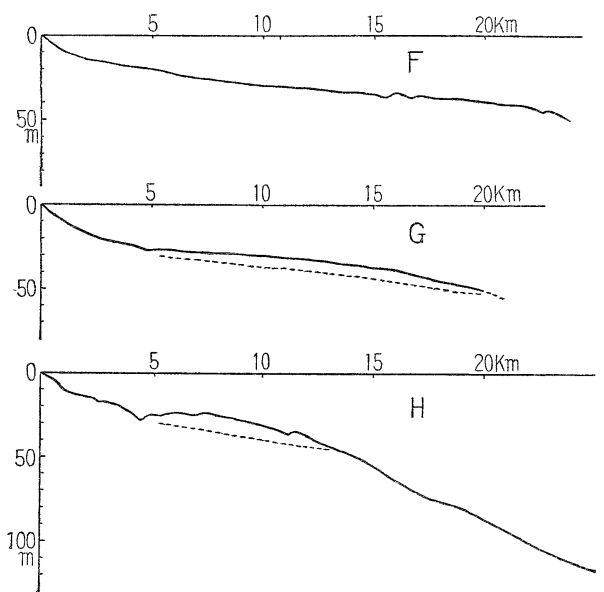

第 9 図常磐北部沖海底断面図 
第 2 表 常磐北部沖底

\begin{tabular}{|c|c|c|c|c|c|c|c|c|c|c|c|}
\hline No. & $\begin{array}{c}\text { 水深 } \\
(\mathrm{m})\end{array}$ & 底質組成 & $\mathrm{Md}$ & So & No. & $\begin{array}{c}\text { 水深 } \\
(\mathrm{m})\end{array}$ & 底質組成 & Md So & No. & $\begin{array}{c}\text { 水深 } \\
(\mathrm{m})\end{array}$ & 底質組成 \\
\hline 1 & 18 & fS & & & 41 & 33 & $\mathrm{~S}$ & 1.780 .3 & 81 & 40 & R.cS.G \\
\hline 2 & 26 & fS & & & 42 & 42 & R.cS.G & & 82 & 39 & $\mathrm{R}$ \\
\hline 3 & 34 & $\mathrm{cS}$ & 0.320 & 0.48 & 43 & 13 & fS.M & $\begin{array}{lll}4.30 & 0.7\end{array}$ & 83 & 50 & M.S \\
\hline 4 & 32 & $\mathrm{cS}$ & -0.05 & & 44 & 13 & fS & 2.820 .4 & 84 & 60 & $\mathrm{cS}$ \\
\hline 5 & 18 & fS & 3.330 & 0.67 & 45 & 28 & $\mathrm{cS}$ & $0.00 \quad 0.3$ & 85 & 76 & M.cS \\
\hline 6 & 12 & fS & 3.750 & 0.34 & 56 & 34 & $\mathrm{fS}$ & 2.490 .2 & 86 & 80 & M \\
\hline 7 & 12 & fS & & & 47 & 43 & $\mathrm{~S}$ & 1. 350.4 & 87 & 102 & M.S \\
\hline 8 & 22 & $\mathrm{~S}$ & 3.740 & 0.38 & 48 & 14 & $\mathrm{cS}$ & 0.50 & 88 & 26 & M.S \\
\hline 9 & 32 & $\mathrm{~S}$ & 1.430 & 0.39 & 49 & 16 & fS & 3.000 .4 & 89 & 24 & R.G.cS.Sh \\
\hline 10 & 32 & S & 1.680 & 0.38 & 50 & 15 & $\mathrm{R}$ & tf. siltston & 90 & 23 & R.cS \\
\hline 11 & 34 & cS.G.Sh & -0.450 & 0.90 & 51 & 13 & $\mathrm{R}$ & dy. siltston & 91 & 27 & R.cs.fS \\
\hline 12 & 14 & fS & 3.800 & 0.58 & 52 & 29 & $\mathrm{cS} . \mathrm{G}$ & $\begin{array}{lll}0.25 & 0.8\end{array}$ & 92 & 34 & $\mathrm{cS} . \mathrm{G}$ \\
\hline 13 & 10 & $\mathrm{~S}$ & 1.930 & 0.63 & 53 & 33 & $\mathrm{cS}$ & 0.000 .5 & 93 & 45 & M \\
\hline 14 & 18 & G.cS & & & 54 & 39 & R.fS & siltston & 94 & 45 & $\mathrm{R}$ \\
\hline 15 & 28 & $\mathrm{cS}$ & 0.250 & 0.45 & 55 & 58 & cS.G.Sh & -0.350 .6 & 95 & 51 & $\mathrm{cS}$ \\
\hline 16 & 32 & $\mathrm{cS}$ & -0.050 & 0.18 & 56 & 13 & $\mathrm{~S}$ & 1.170 .4 & 96 & 64 & $\mathrm{cS}$ \\
\hline 17 & 33 & cS.Sh & -0.651 & 1.00 & 57 & 12 & $\mathrm{R}$ & dy. siltston & 97 & 89 & M \\
\hline 18 & 11 & fS & 2.080 & 0.42 & 58 & 26 & $\mathrm{cS}$ & 0.28 & 98 & 109 & $\mathrm{M}$ \\
\hline 19 & 11 & fS & 3.081 & 1.00 & 59 & 31 & $\mathrm{cS}$ & -0.15 & 99 & 20 & R.S \\
\hline 20 & 21 & $\mathrm{cS} . \mathrm{G}$ & 0.77 & & 60 & 40 & $\mathrm{cS}$ & 0.75 & 100 & 25 & $\mathrm{cS}$ \\
\hline 21 & 27 & $\mathrm{cS}$ & 0.150. & 0.58 & 61 & 13 & $\mathrm{R}$ & tf. siltston & 101 & 28 & R.S.G.Sh \\
\hline 22 & 30 & $\mathrm{cS}$ & -0.40 & & 62 & 10 & fS & 3.150 .2 & 102 & 35 & cS.G \\
\hline 23 & 34 & S.Sh & 1.630. & 0.40 & 63 & 20 & G.cS.Sh & & 103 & 54 & S \\
\hline 24 & 43 & cS.G.Sh & 0.400 & 0.60 & 64 & 26 & $\mathrm{cS}$ & & 104 & 75 & M \\
\hline 25 & 11 & $\mathrm{R}$ & tf. siltst & tone & 65 & 26 & $\mathrm{~S}$ & & 105 & 81 & $\mathrm{cS}$ \\
\hline 26 & 10 & fS & 3.600 & 0.62 & 66 & 29 & $\mathrm{cS}$ & & 106 & 26 & R.cS.Sh \\
\hline 27 & 9 & $\mathrm{R}$ & tf. siltst & tone & 67 & 41 & $\mathrm{~S}$ & & 107 & 30 & $\mathrm{cS}$ \\
\hline 28 & 21 & G.S & & & 68 & 46 & $\mathrm{cS}$ & & 108 & 34 & M \\
\hline 29 & 30 & fS & 2.020 & 0.27 & 69 & 51 & $\mathrm{cS}$ & & 109 & 52 & $\mathrm{cS}$ \\
\hline 30 & 35 & $\mathrm{cS}$ & 0.200 & 0.29 & 70 & 31 & $\mathrm{cS} . \mathrm{G}$ & & 110 & 48 & $\mathrm{~S}$ \\
\hline 31 & 45 & R.cS.Sh & tf. siltst & stone & 71 & 28 & R.S & & 111 & 78 & M.S \\
\hline 32 & 10 & fS & 3.770 & 0.31 & 72 & 37 & cS.G & & 112 & 95 & M.S \\
\hline 33 & 26 & $\mathrm{cS}$ & 0.200 & 0.78 & 73 & 42 & $\mathrm{~S}$ & & 113 & 110 & M \\
\hline 34 & 33 & cS.G.Sh & 0.000 & 0.65 & 74 & 54 & $\mathrm{~S}$ & & 114 & 36 & cS.G.Sh \\
\hline 35 & 34 & $\mathrm{cS}$ & 0.680 & 0.70 & 75 & 65 & $\mathrm{cS}$ & & 115 & 41 & S.MS \\
\hline 36 & 37 & R.S & tf. siltst & stone & 76 & 79 & M & & 116 & 50 & $\mathrm{cS} . \mathrm{G}$ \\
\hline 37 & 10 & fS & 3.200 & 0.54 & 77 & 94 & M & & 117 & 93 & M.S \\
\hline 38 & 10 & fS & 2.980 & 0.60 & 78 & 29 & $\mathrm{cS}$ & & 118 & 110 & M \\
\hline 39 & 14 & $\mathrm{R}$ & if. sandst & tone & 79 & 34 & $\mathrm{cS}$ & & 119 & 21 & $\mathrm{R}$ \\
\hline 40 & 28 & fS & 2. 380 & 0.39 & 80 & 33 & S.M.Sh & & 120 & 27 & R.cS.St \\
\hline
\end{tabular}


質組成表（No. 1～246）

\begin{tabular}{|c|c|c|c|c|c|c|c|c|}
\hline No. & $\begin{array}{c}\text { 水深 } \\
(\mathrm{m})\end{array}$ & 底質組成 & No. & $\begin{array}{c}\text { 水深 } \\
(\mathrm{m})\end{array}$ & 底質組成 & No. & $\begin{array}{c}\text { 水深 } \\
(\mathrm{m})\end{array}$ & 底筫組成 \\
\hline 121 & 27 & $\mathrm{~S}$ & 163 & 14 & $\mathrm{R}$ & 205 & 55 & fS.M \\
\hline 122 & 45 & cS.Sh & 164 & 28 & R.G.cS & 206 & 80 & $\mathrm{M}$ \\
\hline 123 & 53 & $\mathrm{cS}$ & 165 & 27 & G.cS.Sh & 207 & 90 & M \\
\hline 124 & 73 & MS & 166 & 40 & S.Sh & 208 & 111 & M.S \\
\hline 125 & 97 & MS & 167 & 52 & fS.M.Sh & 209 & 128 & M.tS \\
\hline 126 & 116 & MS & 168 & 69 & fS.M & 210 & 134 & $\mathrm{M}$ \\
\hline 127 & 25 & G.cS & 169 & 82 & M.fS.Sh & 211 & 17 & $\mathrm{R}$ \\
\hline 128 & 30 & $\mathrm{R}$ & 170 & 94 & M.fS & 212 & 26 & $\mathrm{fS}$ \\
\hline 129 & 29 & $\mathrm{cS}$ & 171 & 126 & M.fS & 213 & 51 & fS.M \\
\hline 130 & 13 & $\mathrm{R}$ & 172 & 131 & M & 214 & 103 & M \\
\hline 131 & 18 & cS.G.Sh.St & 173 & 14 & R.G.cS & 215 & 123 & M.S \\
\hline 132 & 29 & cS.Sh.G & 174 & 22 & R.M.Sh & 216 & 133 & M.fS \\
\hline 133 & 31 & M & 175 & 32 & cS.Sh & 217 & 58 & fS.M \\
\hline 134 & 39 & $\mathrm{~S}$ & 176 & 42 & fS.Sh & 218 & 95 & M.S \\
\hline 135 & 47 & fS & 177 & 61 & fS.M & 219 & 125 & M.S \\
\hline 136 & 93 & M & 178 & 73 & M.S & 220 & 136 & M.S \\
\hline 137 & 115 & M & 179 & 88 & M.S.Sh & 221 & 12 & S \\
\hline 138 & 127 & $\mathrm{M}$ & 180 & 98 & M.fS & 222 & 26 & S \\
\hline 139 & 10 & cS.Sh & 181 & 121 & M.G.S & 223 & 48 & M \\
\hline 140 & 20 & R.Sh & 182 & 127 & $\mathrm{M}$ & 224 & 68 & fS.M \\
\hline 141 & 26 & R.S.Sh & 183 & 130 & M & 225 & 15 & $\mathrm{~S}$ \\
\hline 142 & 31 & fS.M.Sh & 184 & 13 & fS & 226 & 31 & S \\
\hline 143 & 41 & fS.M.Sh & 185 & 17 & R.fS & 227 & 55 & $\mathrm{M}$ \\
\hline 144 & 51 & fS.M.Sh & 186 & 27 & fS.Sh & 228 & 72 & fS.M \\
\hline 145 & 79 & fS.M & 187 & 37 & fS.Sh & 229 & 90 & M.S \\
\hline 146 & 93 & fS.M & 188 & 67 & fS.M & 230 & 102 & M.S \\
\hline 147 & 101 & M.fS & 189 & 83 & M.S & 231 & 120 & $\mathrm{M}$ \\
\hline 148 & 117 & fS.M & 190 & 96 & M.fS & 232 & 20 & $S$ \\
\hline 149 & 122 & fS.M & 191 & 105 & fS.M & 233 & 38 & S.M \\
\hline 150 & 127 & fS.M & 192 & 126 & $\mathrm{M}$ & 234 & 57 & M \\
\hline 151 & 29 & S.G.Sh & 193 & 15 & $\mathrm{R}$ & 235 & 80 & fS.M \\
\hline 152 & 36 & fS.M.Sh & 194 & 22 & S & 236 & 106 & M \\
\hline 153 & 40 & G.fS.Sh & 195 & 32 & fS.Sh & 237 & 132 & so. $R$ \\
\hline 154 & 47 & fS.M.Sh & 196 & 53 & fS.M.Sh & 238 & 20 & $\mathrm{~S}$ \\
\hline 155 & 61 & fS.M & 197 & 69 & fS & 239 & 42 & S.M \\
\hline 156 & 75 & fS.M & 198 & 84 & M & 240 & 61 & $\mathrm{M}$ \\
\hline 157 & 86 & M.fS & 199 & 109 & M.S & 241 & 25 & $\mathrm{~S}$ \\
\hline 158 & 113 & M.fS & 200 & 119 & $\mathrm{M}$ & 242 & 49 & $\mathrm{M}_{*}$ \\
\hline 159 & 126 & M & 201 & 127 & M & 243 & 70 & M.S \\
\hline 160 & 127 & fS.M.R & 202 & 132 & $\mathrm{M}$ & 244 & 90 & M.S \\
\hline 161 & 23 & M.S & 203 & 33 & fS.Sh & 245 & 106 & M \\
\hline 162 & 11 & R.cS & $204 \mid$ & 45 & S.Sh & $|246|$ & 121 & $\mathrm{cS}$ \\
\hline
\end{tabular}




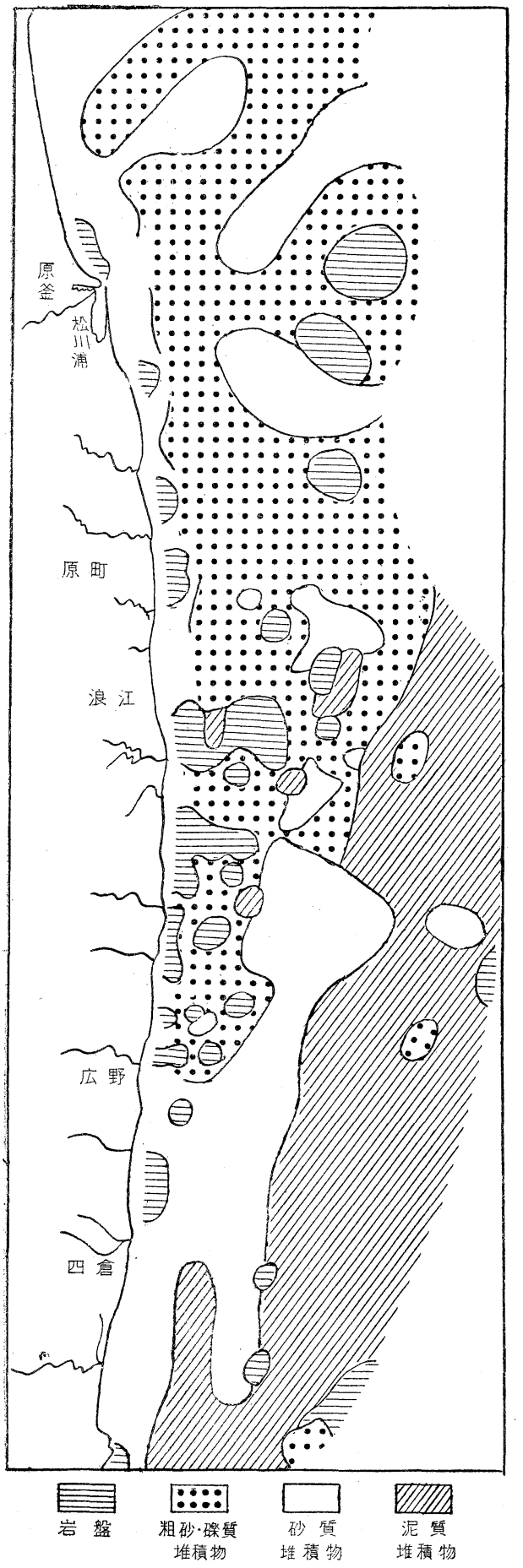

第 10 図 常磐北部沖底質分布図

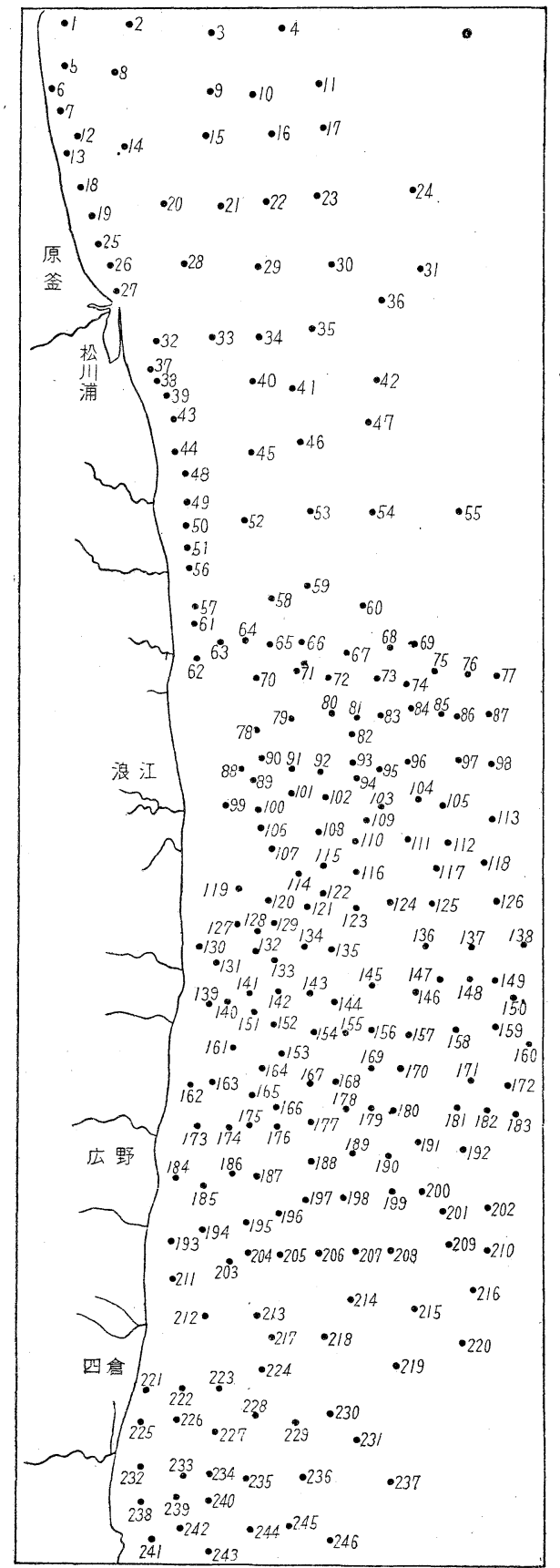

第 11 図常䑾北部沖底質採取地点図 
範囲の含有量である。礫質は chert, sandstone など であるが，chert が最も多い: 28〜48 mesh の組成 分に拈いても， detrital chertは qautz 以上の比率 を占めている. 以上の底質に対して，不饬和的に， 淘汰のよい細砂・中砂が， patch 状に入つてくる。 これらの砂質堆積物は，むしろ $10 \mathrm{~m}$ 付近に広く見 られる堆積物に似ていて， $\phi=2 \sim 4$ の淘汰中のよい 砂である。

2）50m 以深の海底 $50 \mathrm{~m}$ から $120 \mathrm{~m}$ にわたる 海底斜面は，極めてなめらかな，殆んど一様な傾斜 をもつ斜面である。この斜面は北から南へ，海岸と 斜交しながら直線状に走り，南端の塩屋崎付近では， やや傾斜索增す。ここの底質は，北部の浪江沖では，

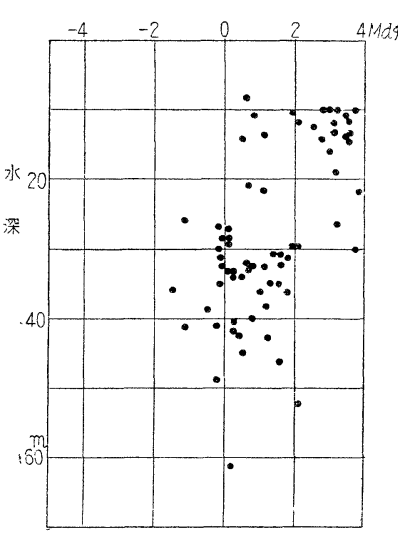

第 12 図 常䑾北部沖海底にお ける粒径と水深との関係
水深 $80 \mathrm{~m}$ 付近 まで粗砂が分布 するが，南部は 細粒で，細砂・ 泥が広く分布す る採取した資 料について見る と, 水深に関係 なく粗粒堆積物 が含まれており， 深度が増すにつ れて, 泥の量が 多くなる，25～50m 平坦面の外縁に連なる。水深 $65 \mathrm{~m}$ 付近では, 殆んど平坦面上の底質と変らない, 淘汰のよい粗砂と granule を含んでいることは注 目に值する。この granule は，斜面末端にも見ら れるが，底質としてはかなり泥質となる。 matrixは green sand といわれるもので，かなりの海緑石を 含文. coarse sand size のものとしては，石英以外 に，浮石・岩石破片等であり，よく円磨されている. 110 120m 付近より再び平坦となり，陸棚外縁平 坦面に移る。この平坦面は，北部に氺いて $120 \sim 150$

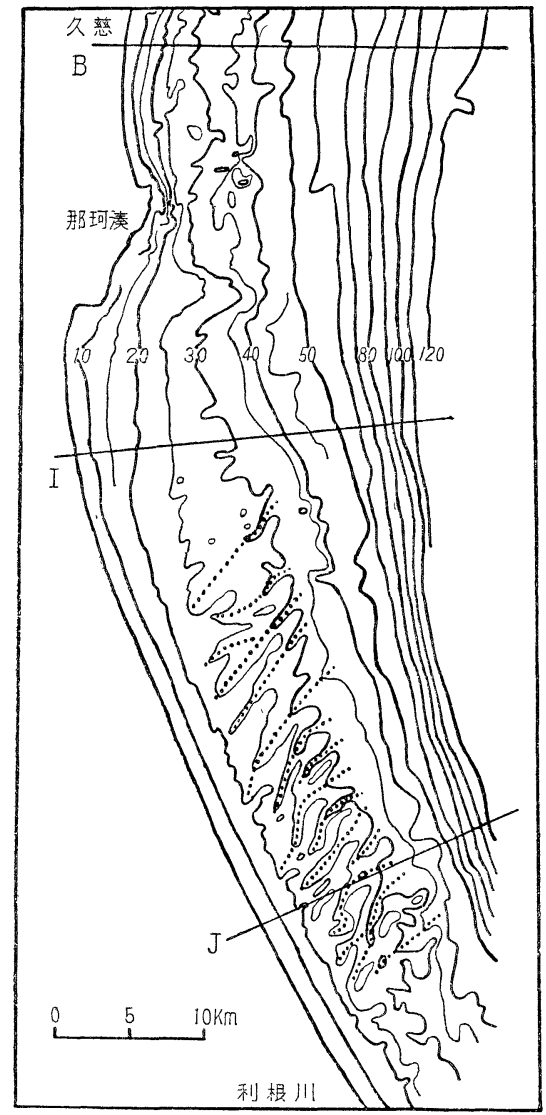

第 13 図 鹿島灘海底地形図

$\mathrm{m}$ ，巾 $20 \mathrm{~km}$ であるが，南に下るに従つて水深・巾 とも減少する，例えば富岡沖では，水深 $110 \sim 140 \mathrm{~m}$ ， 巾 $13 \mathrm{~km}$ となつている. 表面はなめらかで，底質は 一般に $2 \sim 3 \phi$ の fine sand size で，淘汰は悪い. 20〜30\%の泥走含む green sand である。

\section{5。鹿 島 灘}

1） $50 \mathrm{~m}$ 以浅の海底 磯崎から利根川河口にわた るこの海岸は，鹿島台地が広く連なり，ゆるく海方 に巒曲したなめらかな海岸で，ここに注ぐ河川は， 那珂川夌見るだけである。海底地形は，水深約 $50 \mathrm{~m}$ 付近を境に，その以浅の平坦な海底と，以深のやや 急斜した海底とに分けられる. $50 \mathrm{~m}$ 以浅の海底には， 著しい谷状の地形が発達し, その始まる深さ約 $20 \mathrm{~m}$ 


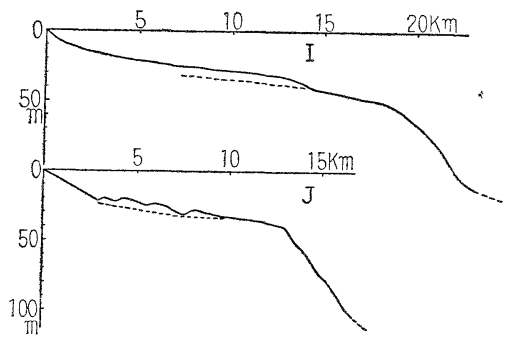

第 14 図 鹿島灘海底断面図

付近を境に，更にその以浅のなめらかな海底と，以 深の起伏の激しい海底とに分けられる(第13 図).

$20 \mathrm{~m}$ 以浅の海底は，東海村の $20 \mathrm{~m}$ 以浅海底に続 く現海成面で，那珂川以南においては，甚だなめら かな地形を示し，旧海図の底質記号によれば，殆ん ど砂の堆積する所である. そのウは約 $2.5 \mathrm{~km}$ で殆 んど一様であるが，大洗岬の南部では $6 \mathrm{~km}$ を示し て広い:これは那珂川の影響を示すもので，入慈川 の場合に見られたような，三角州的性質を有するも のと考えられる.

20〜50m にわたる海底は，全体的に甚だ平坦であ るが，その表面は，比高 $10 \mathrm{~m}$ 未満の, 多数の谷によ つて刻まれた，起伏の激しい海底である。これらの 谷状地形は，鹿島丘陵中部以南の海底に，広く分布 しており，谷の方向は何れも NNE で互に平行して いる．その方向は，現海岸線に対し明かに斜交して 居り, $50 \mathrm{~m}$ 等深線に対してもやや斜交する．海底谷 閒の間隔は約 $2 \mathrm{~km}$ で，海底谷はほぼ同間隔に配列 している，注目すべきことは，これらの海底谷は， 20～50m平坦面上において消失していることである。 すなわち海底谷の末端水深は，1 部で 40～50m を示 す所もあるが, $35 \mathrm{~m}$ の等深線に，すでに谷の地形を 示していないりのが大部分である。一方 20〜50 m 平坦面の外縁水深は，南部で $40 \sim 50 \mathrm{~m}$ ，北部で 50 $\sim 60 \mathrm{~m}$ を示すから, 谷の地形は, 大部分この平坦面 上において消失しており，海底断面は，谷の未端を
境に起伏のある以浅の海底と，一段低い以深の海底 とに区別される.したがつてこの地域の $20 \sim 50 \mathrm{~m}$ 平坦面も，東海村沖や常盤南部沖の様に，厳密には 20〜35m，35〜 50m の 2 つの面からなつているもの と考えられる(第 14 図).

この地域の底質に関する星野17〕の報告によると， 岩盤は殆んど採取されておらず，含まれる礫も少く， 且つ一般に細粒である。旧海図による底質分有を見 ても，殆んど砂・貝殼からなる，唯一ケ所において 岩が採取されているが，この岩盤の採取地点が水深

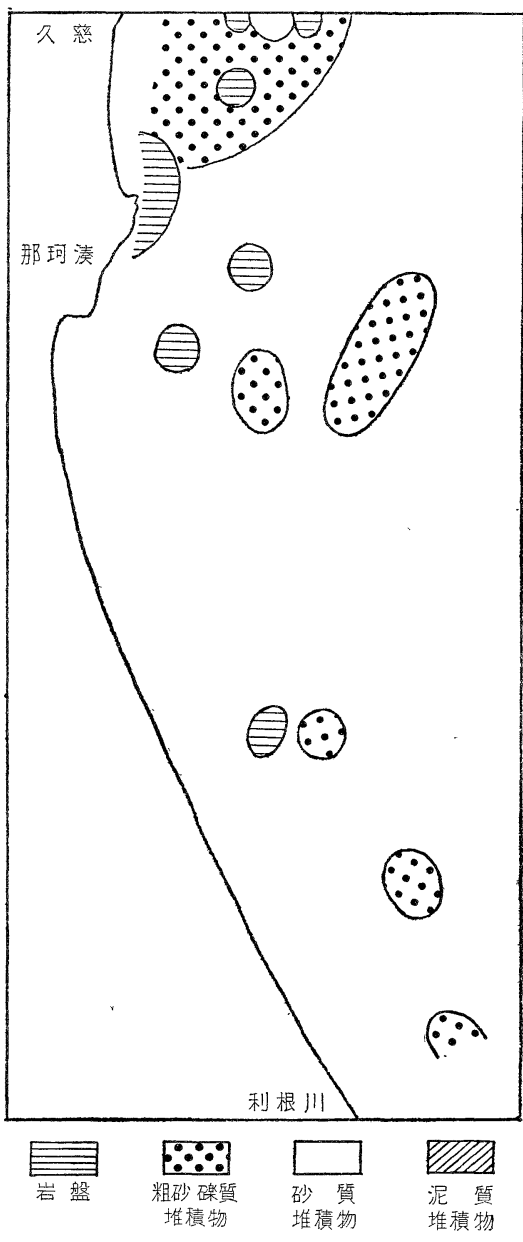

第 15 図鹿島灘底質分布図

17）星野通平（1958）：日本近海大陸棚上の堆積物について。地団研尃報，7，1４0. 
第 3 表 鹿島灘底質組成表

\begin{tabular}{|c|c|c|c|c|c|}
\hline No. & $\begin{array}{l}\text { 水深 } \\
(\mathrm{m})\end{array}$ & 底 質 組 成 & No. & $\begin{array}{l}\text { 水深 } \\
(\mathrm{m})\end{array}$ & 底 質 組 成 \\
\hline 1 & 28 & $\mathrm{G}$ & 31 & 29 & $\mathrm{~S}$ \\
\hline 2 & 34 & R.Sh & 32 & 42 & St.cS.Sh \\
\hline 3 & 49 & $\mathrm{fS}$ & 33 & 65 & $\mathrm{cS}$ \\
\hline 4 & 60 & R.G & 34 & 122 & fSI \\
\hline 5 & 78 & $\mathrm{~S}$ & 35 & 20 & fS \\
\hline 6 & 115 & fS & 36 & 29 & $\mathrm{fS}$ \\
\hline 7 & 27 & G.cS.Sh & 37 & 37 & $\mathrm{fS}$ \\
\hline 8 & 35 & R.G & 38 & 51 & $\mathrm{fS}$ \\
\hline 9 & 67 & cS.Sh & 39 & 120 & fS \\
\hline 10 & 97 & $\mathrm{~S}$ & 40 & 15 & $\mathrm{~S}$ \\
\hline 11 & 28 & cS.Sh & 41 & 30 & $\mathrm{~S}$ \\
\hline 12 & 50 & cS.Sh & 42 & 110 & $\mathrm{~S}$ \\
\hline 13 & 80 & $\mathrm{~S}$ & 43 & 24 & $\mathrm{fS}$ \\
\hline 14 & 101 & fS & 44 & 24 & $\mathrm{~S}$ \\
\hline 15 & 139 & $\mathrm{~S}$ & 45 & 30 & $\mathrm{R}$ \\
\hline 16 & 岸線 & $\mathrm{R}$ & 46 & 31 & G.cS \\
\hline 17 & 岸線 & $\mathrm{R}$ & 47 & 31 & $\mathrm{~S}$ \\
\hline 18 & 31 & S & 48 & 24 & fS \\
\hline 19 & 46 & $\mathrm{~S}$ & 49 & 24 & $\mathrm{~S}$ \\
\hline .20 & 72 & fS & 50 & 18 & fS \\
\hline 21 & 114 & $\mathrm{fS}$ & 51 & 23 & fS \\
\hline 22 & 41 & R.fS & 52 & 32 & cS.Sh \\
\hline 23 & 23 & $\mathrm{~S}$ & 53 & 23 & S.Sh \\
\hline 24 & 40 & $\mathrm{~S}$ & 54 & 17 & fS \\
\hline 25 & 62 & $\mathrm{~S}$ & 55 & 28 & fS \\
\hline 26 & 115 & $\mathrm{cS}$ & 56 & 43 & fS.Sh \\
\hline 27 & 20 & $\mathrm{~S}$ & 57 & 24 & fS \\
\hline .28 & 30 & R.Sh & 58 & 35 & G.cS \\
\hline 29 & 17 & $\mathrm{~S}$ & 59 & 15 & fS \\
\hline 30 & 19 & S & & & \\
\hline
\end{tabular}

$30 \mathrm{~m}$ の海底谷内であることに注目し度い.

2） $50 \mathrm{~m}$ 以深の海底 $50 \mathrm{~m}$ 以深の海底は，急斜 して 110 130m の陸棚外縁平坦面に移る. 50〜110 $\mathrm{m}$ にわたる斜面は，約 $1^{\circ}$ の傾斜をもち，常盤油・東 海村沖の斜面に比べると，著しく急となる.

110 130m 平坦面も，この地域に入ると巾を減じ， 平坦面の傾斜も $35^{\prime}$ となり增大する。

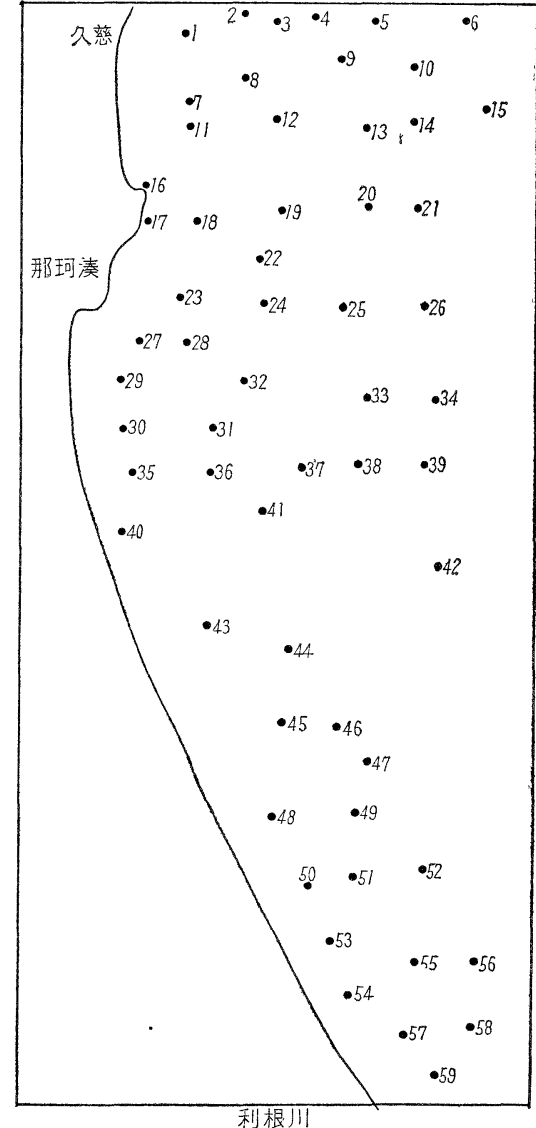

第 16 図 鹿島灘底質採取地点図

\section{6. 考 察}

1）海底地形面 以上の記載から知られるように， 利根川河口から仙台湾にわたる，鹿島灘ならびに常 盤沖の陸棚は，0～20m 面，25～50m 面，および 100 〜140m 面の，3つの地形面からなることが明かで ある。この中， $0 \sim 20 \mathrm{~m}$ 面は現在の海面に関して形 成されつつある現海成面であり，25～50m 面および 100～140 m 面は，過去の地質時代に形成された， 侵蝕面または堆積面であると考えられる，0～20 m の現海成面は，全区域を通じて，ほぼ一様な币を有 し，僅かに那珂川・八慈川河口付近に，三角州状の ふくらみを示すだけである。その地形は, 岬や海蝕 崖の海岸において, 細かい起伏を示しているが，一 
般に甚だなめらかな緩斜面である。一方 $25 〜 50 \mathrm{~m}$ 平坦面は，平均巾 $15 \mathrm{~km}$ を有して甚だ広く，現海 成面はもとより，100～140m 平坦面に比べても，一 般に広い巾を有する。その表面は，多数の盯瞭な海 底谷によつて，浅く刻まれ，甚だ起伏に富んでいる。 海底には，所々第三系の堆積岩が露出し，それらの 間を埋めて, 䃯・granule・粗砂などの粗粒堆積物が 広く分布する．100 140mの陸棚外縁平坦面は，甚 た平坦で，その表面には起伏はなく，底質は粗砂・ granule などの粗粒堆積物を含むが，25～50m 平坦 面に比べれば，一般に細粒である。

この 100〜140m平坦面の形成時代について，吉川 と杉村・貝塚との間に，意見の相異があつたことは， 冒頭において述べた所である・しかしその後，井

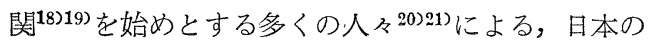
各地における研究の結果，この平坦面が，冲積層下 の旧谷底面に連なるとする考え方が，支配的となつ て来た。

東海村の海岸においても，久慈川および新川の旧 河谷が，冲積層下に埋没されており，その深さは一 $60 \mathrm{~m}$ 抢よびー $30 \mathrm{~m}$ を示しているから，その沖の方 の延長が，100～140m 平坦面に連続すると考えるこ とは，妥当な見方であろう。しかしながら海岸から， 水深 $100 \mathrm{~m}$ の距離は，一般に甚だ大きく，その閒を 陸上に打ける旧河谷底の公配によつて延長し，海底 地形との関係を求めることは，海底の資料のない今 日，止むを得ない方法であろうと思われるが，この 両者の関係の確認は, 海岸と水深 $100 \mathrm{~m}$ との間を, 旧河谷底によつて連結して，始めて達せられる。

本地域に, 陸上河谷加ら連続する, 多数の海底谷 が，25～50m平坦面を切つて，水深約 $50 \mathrm{~m}$ 付近ま で追跡されることは，その意味で注目に值すると思 われる。これらの谷は，海岸に埋没している旧河谷 底を，そのまま示しているのではなく，その後の一 時期を示すりのであるが，旧河谷筋（海底谷）が， 現在の海岸と, 100〜140m 平坦面との間を，結びつ けるように存在していることは，冲積層下の谷底面 と，100〜140m 平坦面との連績性を，かなり有力に 示しているものと思う. 以上のことから，100 140 $\mathrm{m}$ 平坦面は，冲積層下の旧谷底面に対比されるもの であり，海岸に埋没されている旧河谷は，ほぼ現在 海底に見られる谷筋を通つて，水深 $100 \mathrm{~m}$ 付近にお いて，海に注いでいたものと推定される.

25 50m 平坦面は, 東海村海岸の下に埋没してい る，平坦面に績くものであろう。このような関係はッ 東海村付近だけでなく，この地域全体について見ら れるようである。すすなわち常盤南部の大津付近の海 岸におけるボーリング結果では，-15m付近で多賀 層群に達しており，小名浜の冲積層下において夕， 一20m 付近で, 礫層があらわれている。 また原の町 のボーリング結果 ${ }^{22)}$ では，冲積層はー $20 \mathrm{~m}$ で岩盤に 達しているらしく，中野23)によると，千葉県の佐原 付近においても，冲積層の深さは， $-20 \mathrm{~m}$ 前後で あるということである。これらの梁さは，25～50m 平坦面の深さに，甚だよく一致している，したがつ てこの 25 50 m 平坦面の一部は, 各河谷平野の冲積 層下に続いているものと考えられる。この埋没平坦 面と旧河谷面との関係は，東海村におけるボーリン グの結果から，一-60m の旧谷底面が形成された後, 海進に転じ，その海進の一時期に，-15m 以浅の平

18）井関弘太郎（1956）：島根半島付近に認められる沖積世初期の海水準. 地理評.，29,7.

19）-(1958）：日本における海面の相対的変化と冲積層。第四紀研究， $1,2$.

20）桑代 勲（1959）：瀬戸内海の海底地形。地理評。３2,1.

21）岡崎由夫 (1960)：釧路平原とその周辺の地形発達史, 地理評., 33, 9 .

22）経済企画庁（1958）：全国深井地質資料台帳（北海道・東北地方篇）.

23）中野尊正 (1956)：日本の平野。古今書院. 
坦面が，形成されたと考えられている24).したがつ て 100 140m 平坦面と，25 50m 平坦面との関係 も，前者が先に形成され，その後の海進のある時期 に，後者が形成されたと考えられる．25～50m 平坦 面が，100～140m 平坦面よりも先に形成されたと考 えると，後述するように, '25～50m 平坦面を浅く刻 む海底谷の成因を，説明することが困難となる。

2）海底谷 利根川河口より仙台湾にかけての全 地域にわたつて，甚だ明瞭な多数の海底谷が，水深 20～50m 間に存在することは，極めて著しい特徵で， 陸棚の地形発達を考察する上に，甚だ注目に值する 事実である。

これらの谷の存在が示す重要な意味は，100～140 $\mathrm{m}$ 平坦面形成後における大海進の, 途中における海 退の一時期を示しているからである。

これらの谷の成因が，陸上河谷の沈水したもので あることは，これらの海底谷の多くが，極めて密接 に現在の河川に連続していること, 現海岸平野の地 下に埋没した旧河谷が存在すること，海底平坦面や 底質分布から，現海底に旧海岸線を容易に想定する ことができることなどによつて，もはや疑う余地は ないであろう。しかしこれらの谷が，陸上河谷の沈 水したものであることを認めたとしても，それがい つどのような過程で形成されたかに，大きな問題が ある，前節で述べたように，この地域の海底谷の成 因は，これらの谷が 100 140m 平坦面形成期 (洪積 世最末期の海面低下）に形成された谷の，埋め残さ れたものであるとする説と，その後に再び作られた むのであるという考え方の，2つに大きく分れるで あろう。岡崎 ${ }^{25)}$ ・井関26)等は前者の説をとつている が，筆者等は後述するような理由から，冲積世初期 海進の途中に打ける 1 海退期に形成されたものと考
えている.

すなわちこの地域の海底谷は，いずれも $25 \sim 50 \mathrm{~m}$ 平坦面を，ほぼ一様に浅く刻んでおり，その末端は 大体一線に配列して，50１00m の広い斜面部には， 全くその痕跡を見ない. 100〜140m に開口した谷が， 埋め残されて現在のような地形を示すことは，容易 に考え難いように思われる。これらの谷が，海進の 途中で再び刻まれたとする有力な証拠は，谷内に岩 盤が露出していることと，谷の未端に旧海岸線を指 示する様な, 粗粒堆積物や狭い平坦面を残している ことである。すなわち鹿島灘中部の St 45 は，明か に海底谷内から採取されたりのであるが，岩盤を示 して抢り，また常盤南部沖の花園川に続く海底谷内 からも，2点において岩盤を採取した。海底谷が埋 め残されたものであるためには，数 $10 \mathrm{~m}$ の厚さの 堆積物によつて，埋められていなければならないの であるが，谷内における岩盤の存在は，一部の谷に おいては，殆んど埋められていないことを示してお り，海進の途中で新たに谷が刻まれた事実を示して いるものである。 また東海村沖や鹿島灘においては。 海底谷の末端に1段低い狭い平坦面が存在し，加賀 美等による27)と，この部分において底質は再び粗粒 になるという，常盤南部沖の，谷内から水深 $50 \mathrm{~m}$ 付 近まで続く広い平坦面为，或はこの面に対比される のかむ社れない，常盤北部沖に抢いては，平坦面の 地形は不明であるが，斜面上部（海底谷末端）に， やはり granule や粗砂などの粗い堆積物が存在して， 一時期の海岸線を暗示している．以上の事実から， 現在 25〜 50m に見られる浅い海底谷は，洪積世最 末期の海面低下の際に，深くけずられた谷の埋め残 されたものではなく，その後の海進の途中に海退の 一時期があつて，その時に新たにけずられたもので

24）小池一之 (1960)：茨城県東海村付近の地形発達. 第四紀研究，1,7.

25）岡崎由夫 (1960) ・ 北海道釧路平原の冲積世古地理. 第四紀研究, 1, 7.

26）井関弘太郎・幸島荘八郎（1959）：名古屋港付近における冲積層下底面の地形。地理評.，32,9.

27）前揭 6). 
あることは，ほほほ疑いないと思われる23)。

水深 20 〜 $60 \mathrm{~m}$ の浅く谷によつてけずられた海底 地形を見ると，現在の海岸平野に著しく類似してい ることに気付くであろう。これは，この海底が現在 の海岸平野と同じような過程を経て作られたことを 示しており，前述の推論をさらに裏付けるものであ る. Bradley によれば29)，広い平坦面が形成される ためには，ゆるやかな海面上昇を伴わなければなら ないという。

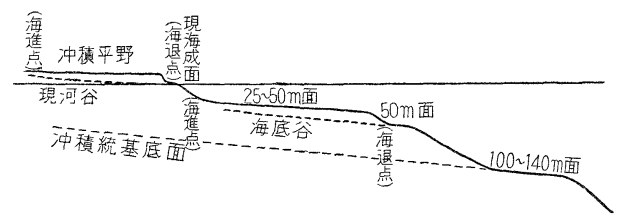

第 17 図 陸棚の形成機構を示す概念困

狭い現海成面（海退期）に対して，広い現在の冲 積平野面は，確かに海進期の産物であり，この冲積 平野に著しく類似する，広い20～50m面と狭い $40 \sim$ $60 \mathrm{~m}$ 面との関係も, 同様にゆるやかな海進期と, そ れに続く海退期の産物であることを意味するものに 違いない，常盤北部沖の $25 \sim 50 \mathrm{~m}$ 平坦面は，北部 の原釜沖において甚だ広く，南の方にくるに従つて 漸次狭まり，遂に広野付近で消失するような，特徵 のある分布形態を示している。海岸平野の広さにも， こ机と似たような分布が示されている。このことも 両者の形成機構に，共通したものが存在することを 意味するものであつて，これらの平坦面の巾が，海
進期と海退期とにおける，夫々の海岸線間の距離に よつて示されることを物語るものである。北部仙台 湾においては傾斜が非常に緩いため，海進期と海退 期における海岸線の移動量が大きく，南部において は傾斜が大きいため，等量の海面変化に対しても， 海岸線の移動量が小さかつたことを示す。しかし広 野以南の海岸に, 25〜 50m 平坦面が欠除している原 因は，大倉 ${ }^{30)}$ が海岸段丘の分布から指摘したように， 堅硬な地質に原因するものであろう。

このように陸棚上に見られる海底谷の存在は，あ る時期における海退期の存在を意味する点で，甚だ 重要である。しかし今日知られている限り，このよ うに海底谷が顕著に発達している地域は，日本周辺 に抢いては，この常盤沖・鹿島灘以外には知られて いないが，局部的な分布は，日本の各地に打いて見 られる ${ }^{31)}$.

渡島半島の周辺に見られる海底谷は, 現河口より 連続し，中閒段丘である $25 ４ 5 \mathrm{~m}$ の平坦面を浅く 刻んで， $40 \sim 45 \mathrm{~m}$ 付近で消失しており ${ }^{32}$, 能登沖の 海底にも，50〜60m の中間段丘圭浅く刻む海底谷が ある33)。

島原海湾の早崎海陕には，天草島の内野川から続 く，顕著な海底谷があり，やはり中間段丘である 15 ３0m の平坦面を浅く刻んで，その段丘末端で消失 している ${ }^{34)}$ 。これらの海底谷の性質は，全く本地域 に見られるものと同様であつて，日本周辺の多くの

28）このような冲積伳初期の海進の途中に，海退の一時期が存在した事実は，東海村海岸に打けるボーリング 結果にも示されている。 - $60 \mathrm{~m}$ を示す久慈川の旧河谷底には，谷を刻んだ当時の礫層が存在するが，そ の上部一 $40 \mathrm{~m}$ に再び㗂層があらわれている。この礫層は海進の途中における海退の一時期を示すもので あろうと解釈される。

29) Bradley. W. C. (1958) : Submarine abrasion and wave cut platforms. Bull. Geol. Soc. Amer., 69, $967 \sim 974$.

30）大倉陽子（1958）：阿武郎山地東北縁部の段丘地形。地理評.，31,4.

31）矢部長克・田山利三郎（1934）：日本近海海底地形概観。震研彙報，，12,3.

32）茂木昭夫 (1958)：津軽海峡西部の海底地形。地理評., 31, 1

33）-(1956)：能登沖の海底地形。東北地理。9,2.

34）—・佐藤任弘・梅田次昌（1959）：島原海湾の海底地形・底質分布预よび潮流. 海上保安庁水路部 調査報告。 


\begin{tabular}{|c|c|c|c|c|}
\hline 時代 & 㘸上地形面 & 海底平坦面 & 谷 & 海 面 变 化 \\
\hline \multirow[b]{2}{*}{ 冲 } & & Q 20m面 & 冲栍平野の開析㫜河公 & $0 \quad-50 \quad-100$ \\
\hline & 冲積平野面 & & \multirow{3}{*}{$\begin{array}{c}25 \sim 50 \mathrm{~m} \text { 平坦面の開析 } \\
(\text { 現海唇谷) }\end{array}$} & \\
\hline \multirow{2}{*}{ 積 } & \multirow[t]{2}{*}{ ? } & 40 $60 \mathrm{~m}$ 平坦面(?) & & \\
\hline & & & & \\
\hline \multirow[t]{2}{*}{ 世 } & $\begin{array}{l}\text { 埋没段平面 } \\
(-15 \sim 20 \mathrm{~m})\end{array}$ & 25 50m平坦面 & \multirow[b]{2}{*}{ 海底谷の埋没 } & \\
\hline & & 50 100m海底斜面 & & \\
\hline \multirow{3}{*}{$\begin{array}{l}\text { 洪 } \\
\text { 積 }\end{array}$} & 埋没谷底面 & $100 \sim 140$ 平坦面 & \multirow{3}{*}{$\begin{array}{l}\text { 久恝川-60m 旧谷の } \\
\text { 形成 } \\
\text { (海底 谷 つ) }\end{array}$} & \\
\hline & & & & \\
\hline & & & & \\
\hline
\end{tabular}

第 4 表 陸棚の地形編年と海面変化

地域に打いて，冲積世初期の海進の途中に，海退の 一特期が存在したことが推定される。またこのよう な谷の存在しない所は，その後に埋積されたか，地 盤運動の影響によるかのいずれかであろう。

3）地形発達 以上の考察に基づき，この地域の 地形発達を編めば，次のようになろう。

（1）陸上の諸段丘を形成した後，海面は，現在の 水深 $100 \mathrm{~m}$ 付近まで降下した，海面降下は，現在の 水深 $100 \mathrm{~m}$ に近い䪸から，漸次緩やかとなり，110 〜 $120 \mathrm{~m}$ 付近において極大となり，その後は海進に 転じて，緩やかに上昇し始めた。現在の水深 100 $140 \mathrm{~m}$ 平坦面は，この海退の極大期に形成された。

Bradley によれば，著しく広い平坦面が形成される ためには，ゆるやかな海面上昇を伴わなければなら ないということであるから，恐らくこの広い平坦面 は，海面降下の極大期から，緩やかな海面上昇に向 う過程に执いて，形成されたものと思われる。この 海迠に際して，陸上の諸河川は，延長川となり，現 在の水深 $100 \mathrm{~m}$ 付近に打いて海に注き，この侵蝕基 準面に対して，深く陸上を下刻した。 現在久慈川の 下に埋没されている，-60mの旧谷底面は，この時 に形成されたものである。
（2）その後，海面は急速に上昇し たが，現在の水深 $30 \mathrm{~m}$ 付近から漸 次緩やかとなり，水深 $15 \mathrm{~m}$ 前後の 所に新いて，海面の上昇は極大に達 した. 現在の 25〜 $50 \mathrm{~m}$ 平坦面は，こ のゆるやかな海進期に形成されたも のである.そして現在の水深 $100 \mathrm{~m}$ から $15 \mathrm{~m}$ まだの海進期に際し，海 面下に没した河谷は，上流からの土 砂の供給と, 25〜 50m 平坦面形成に 伴う海蝕とによつて，殆んどその形を留めないまで に堆積された.

（3）その後，逆に海面は降下し始めて，海退に転 じた。この海退は現在の水深 $50 \mathrm{~m}$ 付近において留 まり，50〜60m 付近に，粗い海浜堆積物を残し，一 部には狭い海蝕面を形成した。この海退期に掞いて， 陸上河川は再び延長川となり，現在の水深 $50 \sim 60 \mathrm{~m}$ 付近を基準面として，25～50m 平坦面走浅く下刻し た。この結果，現在海底に見られるような浅い谷が 形成された。

（4）その後再び急速な海進に転じた。海面上昇に 際し，水深 $15 \mathrm{~m}$ 付近までは著しく平坦な地形であ るため，海進の速度は著しく速やかであつたと思わ れる。その結果，殆んど谷は埋められず35)，海底谷 として残された。海進は現在の高さ $4 \sim 5 \mathrm{~m}$ の所ま で進み，海底には，浅くて広い平坦面か汧成された。

（5）その後海面は 4 5m 降下して，現在の海岸 に位置した。そのため広い海底面は，陸化して浅く 河谷によつて刻まれ，現在見られるような海岸平野 を形成した。

\section{7.あとがき}

常盤沖から鹿島灘に続く陸棚は，狭い20m 以浅

35）この時期の海進で，殆んど顕著な堆積作用がなかつたことは，現在の $20 〜 60 \mathrm{~m}$ の海底に広く岩盤があら われ，平坦面形成時の産物と思われる碟や粗砂などの粗い堆積物が直接分布していることからもうかが わ机る。 
[34. 3

の現海成面と，浅く谷によつて刻まれた広い $25 〜 50$

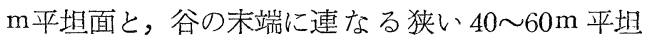
面，および 100～140m に連なる陸棚外縁平坦面の， 4 つの地形面によつて構成される. 陸棚外縁平坦面 は，冲積層下の谷底面に連なるもので，洪積世最末 期の海面降下の際に形成され，25～50 m 平坦面は， その後の冲積世初期海進の途中において，海進がゆ るやかになつた時の産物である，その面上を浅く刻 む海底谷およびその末端に連なる狭い 40～60m 平 坦面は，それに続く一海退期の際に形成されたもの
である。この様な海面変化の過程は，氷期に打ける 大きな海面変化の中に，小規模な海面変化が存在し たことを示すものである，陸棚のような，地質時代 の新しい地形についてはここような海面変化によ つて説明することが出来るが，それ以前の地形につ いては，地盤運動の影響を考慮しないでは，説明で きなくなるのではあるまいかと予想される。

本測量を実施した諸岡保安官以下第三管区海上保安本部および第二 管区海上保安部水路部測量班員の諸氏ならでに本稿をまとめるに当つ て, 種々御助言をいだいた星野通平・佐藤任弘の両氏に澡く咸謝の意 を表する（1960 年 12 月 13 日）。

\section{SUBMARINE TOPOGRAPHY AND SEDIMENTS ON THE CONTINENTAL SHELVES ALONG THE COASTS OF JŌBAN AND KASHIMANADA}

\section{Akio MOGI and Yoshio IWABUCHI}

As the results of the survey of the continental shelves along the coasts of Kashimanada and Joban Pacific, the authors have found that these shelves are composed of four terraces, one less than 20 meters. in depth, one 25 to 50 meters, one 40 to 60 meters and one 110 to 140 meters in depth.

The terraces, less than 25 meters in depth, have been built by the deposition or abrasion along the coasts concerning the present sea level.

The terraces, 25 to 50 meters in depth, extend about 10 kilometers in width along these coasts. On theseterraces, rock, gravel and coarse sand bottoms predominate, and surfaces of the terraces are cut down by several submarine valleys.

The terraces, 40 to 60 meters in depth, are narrow in width and located on the offshore part of submarine valleys.

The terraces, 110 to 140 meters in depth, have flat profiles. On the southern part of Kashimanada, these terraces become narrower in width and steeper in inclination.

The topographic development of these continental shelves is as follows.

In the latest Pleistocene, the sea-level lowered about 100 meters below the present sea level, and the valley now buried under the R. Kuji was cut down to about 100 meters below the present sea level. In the begining of Holocene, the sea level rose about 80 meters and abrasion platforms were built at the depth of 25 to 50 meters. Then the sea level lowered again to the depth of about 50 meters below the present sea level. During the lowering of the sea level, valleys were again cut down to about 50 meters below the present sea level and narrow abrasion platforms were built at a depth of 40 to 60 meters. Then, the coastal plains were built by the regression succeeding the transgression up 4 to 5 meters above the present sea level which extensively affected the coasts of the Japanese Islands. 